\title{
The Complex Formed by Group I Metabotropic Glutamate Receptor (mGluR) and Homerla Plays a Central Role in Metaplasticity and Homeostatic Synaptic Scaling
}

\author{
${ }^{\circledR}$ Joël Bockaert, ${ }^{1}{ }^{\circledR}$ Julie Perroy, ${ }^{1}$ and Fabrice Ango ${ }^{2}$ \\ ${ }^{1}$ Institut de Génomique Fonctionnelle, Université Montpellier, Center National de la Recherche Scientifique, Institut National de la Santé et de la \\ Recherche Médicale, 34094 Montpellier, France, and ${ }^{2}$ Institut des Neurosciences de Montpellier, Université Montpellier, Center National de la \\ Recherche Scientifique, Institut National de la Santé et de la Recherche Médicale, 34295 Montpellier, France
}

G-protein-coupled receptors can be constitutively activated following physical interaction with intracellular proteins. The first example described was the constitutive activation of Group I metabotropic glutamate receptors (mGluR: mGluR1,5) following their interaction with Homerla, an activity-inducible early-termination variant of the scaffolding protein Homer that lacks dimerization capacity (Ango et al., 2001). Homerla disrupts the links, maintained by the long form of Homer (cross-linking Homers), between mGluR1,5 and the Shank-GKAP-PSD-95-ionotropic glutamate receptor network. Two characteristics of the constitutive activation of the Group I mGluR-Homerla complex are particularly interesting: (1) it affects a large number of synapses in which Homerla is upregulated following enhanced, long-lasting neuronal activity; and (2) it mainly depends on Homerla protein turnover. The constitutively active Group I mGluR-Homerla complex is involved in the two main forms of non-Hebbian neuronal plasticity: "metaplasticity" and "homeostatic synaptic scaling," which are implicated in a large series of physiological and pathologic processes. Those include non-Hebbian plasticity observed in visual system, synapses modulated by addictive drugs (rewarded synapses), chronically overactivated synaptic networks, normal sleep, and sleep deprivation.

\section{Introduction}

G-protein-coupled receptors (GPCRs) spontaneously adopt many different active and inactive conformations (Nygaard et al., 2013; Chan et al., 2019; Du et al., 2019). Different agonists can stabilize different active states of a single GPCR, activating distinct signaling pathways. This pharmacological property is called biased agonism or ligand-dependent selectivity (Christopoulos and Kenakin, 2002; Luttrell et al., 2015). For many years, it has been thought that GPCRs could only be activated by extracellular ligands. We know now that GPCRs can also be activated by membrane depolarization (Perroy et al., 2002; Bezanilla, 2008; Vickery et al., 2016), structural modifications caused by mutations (Lefkowitz et al., 1993; Scheer et al., 1996; Vassart and Costagliola, 2011), phosphorylation (Miller et al., 2003; Delcourt et al., 2007; Liggett, 2011; Nobles et al., 2011; Duhr et al., 2014; Karaki et al., 2014; Murat et al., 2019), interactions with small pharmacological ligands (Oswald et al., 2016; Zheng et al., 2016; Liu et al., 2017, 2019), or soluble intracellular GPCR interacting proteins (GIPs) (Ango et al., 2001; Fagni et al., 2004; Bockaert et

\footnotetext{
Received Jan. 6, 2021; revised May 5, 2021; accepted May 6, 2021.

This work was supported by Center National de la Recherche Scientifique, Institut National de la Santé et de la Recherche Médicale, and Université de Montpellier. We thank Patrick Carroll for constructive criticism of the manuscript.

The authors declare no competing financial interests.

Correspondence should be addressed to Joël Bockaert at joel.bockaert@igf.cnrs.fr.

https://doi.org/10.1523/JNEUROSCI.0026-21.2021

Copyright $\odot 2021$ the authors
}

al., 2010; Deraredj Nadim et al., 2016; Pujol et al., 2020). Twenty years ago, we published the first example of an agonist independent (constitutive) activation of mGluRla and mGluR5 by an intracellular GPCR interacting protein: Homerla (Ango et al., 2001).

The C-terminal tail of Group I mGluR contains a binding site (TPPSPF) able to interact with the N-terminal enabled/VASP homology (EVH)-like domain (EVH1) of Homer proteins (Brakeman et al., 1997; Kato et al., 1998; Tu et al., 1998; Xiao et al., 1998; Fagni et al., 2002). There are two classes of Homer proteins (Fagni et al., 2002; Shiraishi-Yamaguchi and Furuichi, 2007). The first one, comprising Homer1b, 1c, 2, and 3, has long C-terminal coiled-coil domains which form a tetrameric Hub structure composed of two antiparallel dimers at the glutamatergic postsynaptic density (Hayashi et al., 2006, 2009). A dimer (or tetramer) of long C-terminal forms of Homer crosslinks different proteins and connects, for example, Group I mGluR with downstream signaling molecules containing a Homer binding site (PPxxFR). These are called "cross-linking Homers."

The second class of Homer proteins comprises two truncated forms of Homer1, Homerla and Ania-3, which share similar protein sequences, except for few residues at the $\mathrm{C}$-terminal end (Brakeman et al., 1997; Bottai et al., 2002). They are the products of activity-induced immediate early genes. Homerla lacks the Cterminal dimerization domain, but contains, as the other Homers, an EVH1 domain (Tu et al., 1998; Xiao et al., 1998; Shiraishi-Yamaguchi and Furuichi, 2007). It can thus bind to 
A

Glutamatergic spine under basal conditions
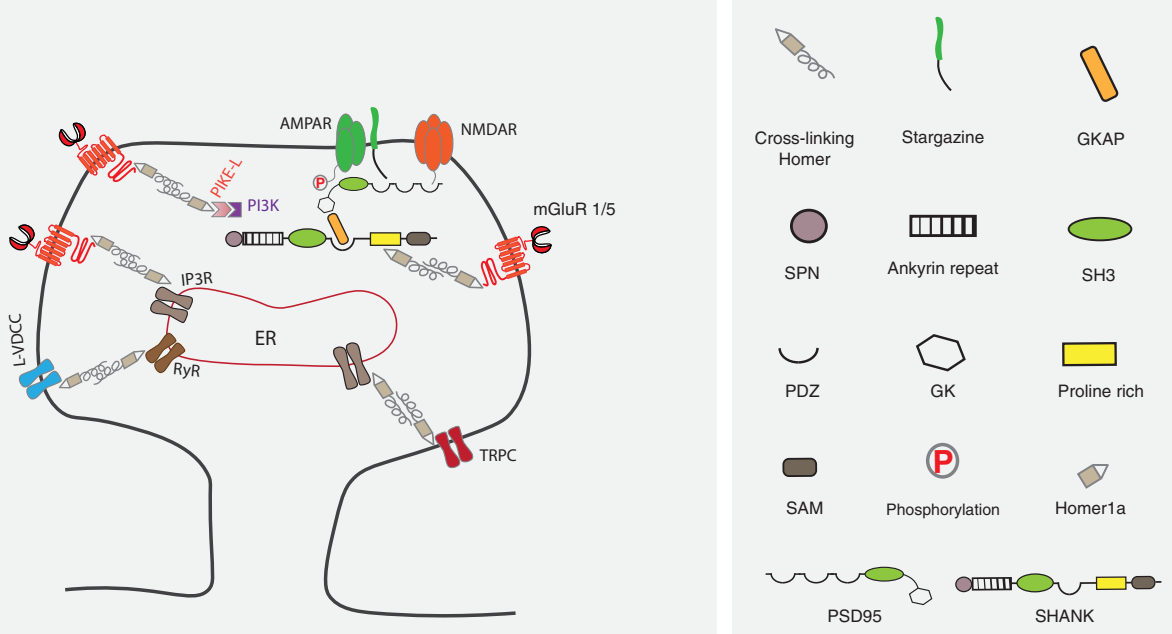

\section{B Spine signaling after activity-induced upregulation of Homer1A}

B1
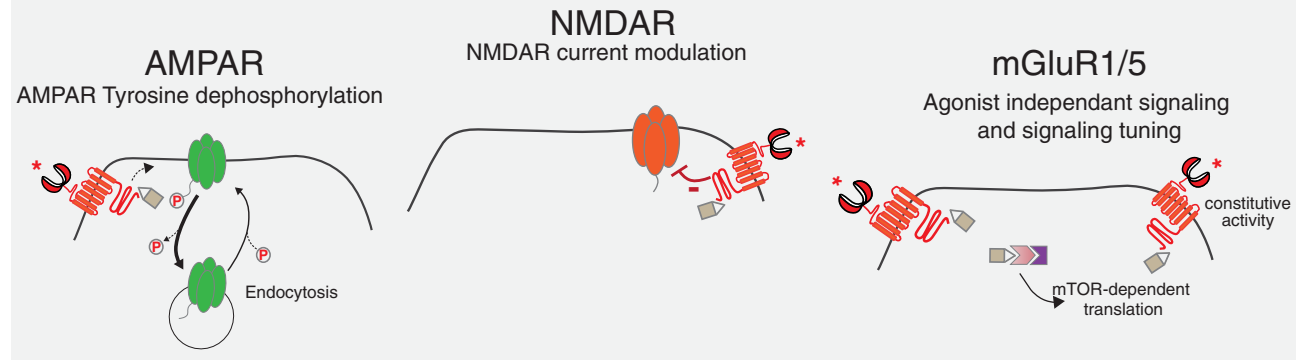

B2
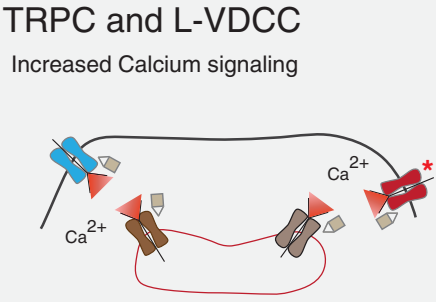

mGluR1/5

Agonist independant increased in IP3R $\mathrm{Ca}^{2+}$ released

Figure 1. Spine signaling under basal conditions and after activation induced Homer1a accumulation. $\boldsymbol{A}$, Under basal conditions, glutamate receptors, channels, and intracellular platform proteins are cross-linked by cross-linking Homers. $\boldsymbol{B}$, After neuronal activity induced Homer1a accumulation, spine signaling is remodeled. $\boldsymbol{B} 1$, The constitutively active mGluR1,5-Homer1a complex triggers dephosphorylation and internalization of AMPARs (left), physically interacts and inhibits NMDARs (middle), and allows the constitutive activation of PI3-kinase and mTOR (right). B2, Homer1a also frees cross-linked $\mathrm{Ca}^{2+}$ channels, increasing their activity (TRPC and L-VDCC, left) while the constitutively active mGluR1,5-Homer1a complex increases PLC activation, leading to increased activity of IP3 receptors and thus $\mathrm{Ca}^{2+}$ release from the ER (mGluR1/5 agonist-independent increase in IP3R $\mathrm{Ca}^{2+}$ release, right). ${ }^{*}$ The mGluR1,5 receptors or TRPC channel are constitutively activated.

proteins containing a Homer binding site and act as a "dominant negative" interactor that disrupts the complexes formed by cross-linking Homers. In particular, Homerla releases Group I mGluR from the postsynaptic network maintained by cross-linking Homers (Kammermeier et al., 2000; Xiao et al., 2000) (Fig. 1). This results in constitutive activation of the receptors in the absence of glutamate (Ango et al., 2001). The constitutively active Group I mGluR-Homerla complex has been reported to be a key actor in Hebbian synaptic plasticity (Clifton et al., 2019) but also in non-Hebbian neuronal plasticity: metaplasticity and homeostatic synaptic scaling (J. H. Hu et al., 2010; Diering et al., 2017; Chokshi et al., 2019b; Holz et al., 2019; H. K. Lee and Kirkwood, 2019; Marton et al., 2015).

Homerla is synthetized via activity-inducible premature termination of transcription of the Homer gene, downstream of exon 5. Homerla is produced under a great variety of physiological, pathologic, and pharmacological conditions, generally resulting in neuronal excitation (Bottai et al., 2002). For example, Homer1a is induced by neuronal depolarization (Ango et al., 2000, 2001), BDNF activation (Mahan et al., 2012), epilepsies (Li 


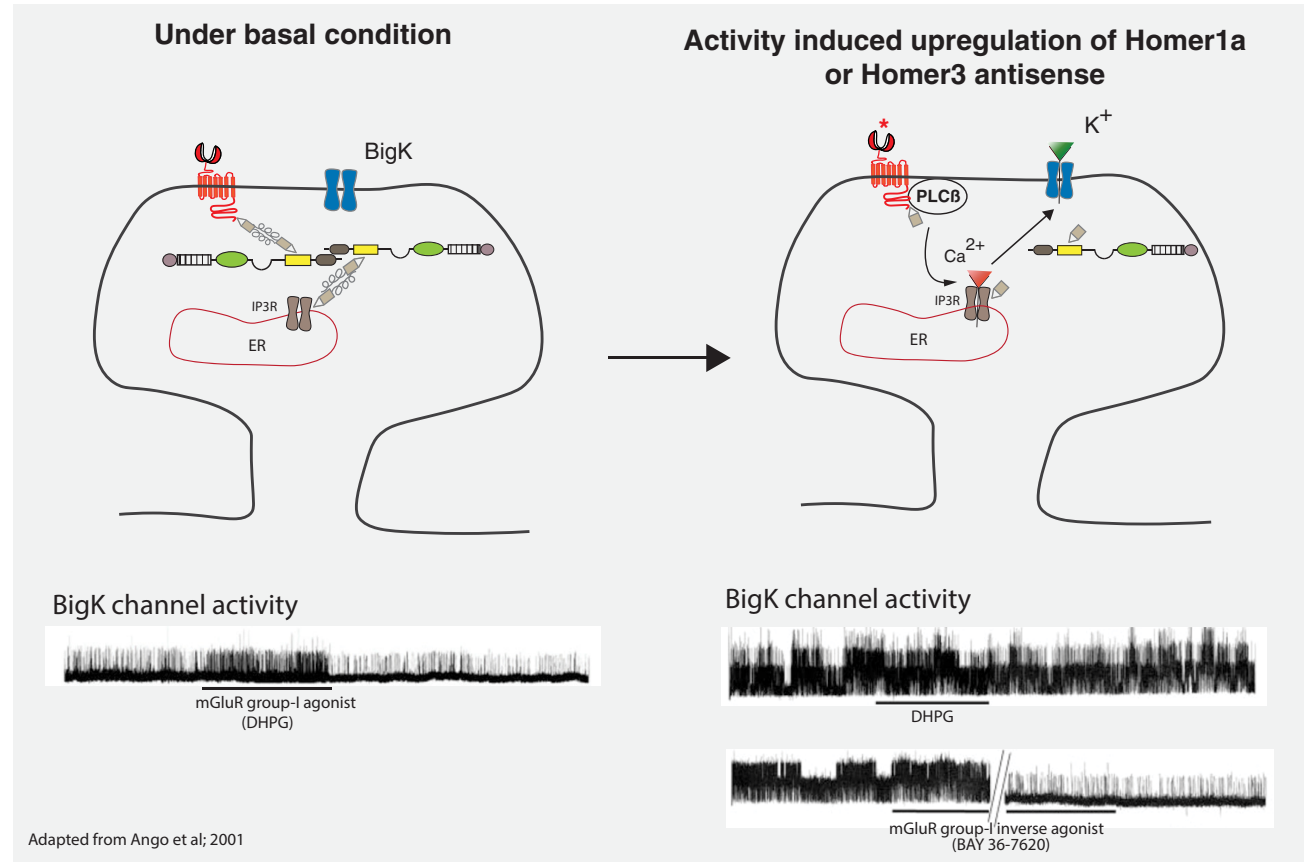

Figure 2. The constitutively active mGluR1,5-Homer1a complex strongly activates BigK channels in cerebellar granule cells. Left, Under basal conditions, mGluR1 and Shank are cross-linked by Homer 3. Transient activation of mGluR1 by an mGluR1,5 agonist (DHPG) activates, in a reversible manner, BigK channels recorded in cell-attached patches (physiological recordings shown underneath). Right, Homer3 antisense or activity-induced Homer1a induction releases mGluR1 from cross-linking, and they become constitutively active. This leads to constitutive activation of BigK channels recorded in cell-attached patches (physiological recordings shown underneath). The BigK channels are recorded in cell-attached patches. Application of DHPG does not further activate these channels, whereas application of an mGluR1 inverse agonist (Bay 36-7620), but not a neutral antagonist (not shown), inhibits the constitutive activation of BigK channels. ${ }^{*}$ The mGluR1,5 receptors are constitutively activated.

et al., 2012), traumatic injury (Luo et al., 2014), LTP, exposure to psychoactive drugs (Swanson et al., 2001; Szumlinski et al., 2006, 2008; Zhang et al., 2007; Marton et al., 2015), strong AMP production (Zhang et al., 2007; Marton et al., 2015), fear conditioning (Tronson et al., 2010), adenosine A1 receptor activation (Serchov et al., 2015), visual experience following dark rearing (Brakeman et al., 1997; Chokshi et al., 2019b), maintenance of ocular dominance (Chokshi et al., 2019a), neuropathic and inflammatory pain (Miyabe et al., 2006; Tappe et al., 2006), and certain antidepressant treatments (Serchov et al., 2015; Holz et al., 2019).

\section{Homer 1a remodels postsynaptic glutamatergic synapse signaling and structure}

Ionotropic glutamate receptors and channels of spines are interconnected by cross-linking homers. Glutamate receptors are inserted into a dense protein network. NMDARs and AMPARs (via stargazin) are associated with the scaffolding protein PSD-95 or its homologs, forming a platform (Kim and Sheng, 2004). PSD-95 is also connected, via GKAP, to a second platform constituted by sheets of Shank protein (Kursula, 2019). Shank contains an N-terminal conserved SPN (Shank/ProSAP N-terminal) domain followed by ankyrin repeats, an $\mathrm{SH} 3$ domain, a PDZ domain, a "Homer ligand" domain (PPXXF), and a C-terminus containing a SAM domain able to form supramolecular lattices (Kursula, 2019). Like Group I mGluR and Shank, many proteins of the postsynaptic site, and in particular those implicated in $\mathrm{Ca}^{2+}$ homeostasis, contain a Homer ligand domain. Those include inositol 1,4,5-triphosphate receptors (IP3-Rs), ryanodine receptors (RyR), transient receptor potential cation (TRPC) channels, phospholipase (PLC) $\beta$, L-type and P/Q-type voltagedependent calcium channels (VDCCs), phosphoinositide 3-kinase (PI3K) enhancer-long (PIKE-L), and dynamin III (Fagni et al., 2002; Gray et al., 2003; Bockaert et al., 2010; Clifton et al., 2019). The EVH1 domain of cross-linking Homers is able to bind the Homer ligand domain of these proteins, and bind them together. For example, cross-linking Homers link Group I mGluR to Shank, IP3-R, Pike and Dynamin III, TRPC channels to IP3-R and L VDCC to RyR (Fig. 1) (Fagni et al., 2002, 2004; Bockaert et al., 2010; Clifton et al., 2019).

Considering this dense cross-linking of receptors and channels by cross-linking Homers, it is not surprising that Homer 1a, acting of a "dominant negative" of these links, remodels spine signaling events.

We described (20 years ago) one of the major effects of Homerla on spine signaling. Using cerebellar granular cells, in which we were studying, activation of large-conductance potassium (BigK) channels by endogenously expressed mGluR1a or transfected mGluR5. These cells express only one cross-linking Homer (i.e., Homer3). We studied the effect of its suppression (using an antisense strategy) on the mGluR-induced BigK channel activation. Results were spectacular (Ango et al., 2001). The BigK channel became highly active, much more than when mGluRla was stimulated by glutamate. Mutation of the Homer ligand domain of mGluR or overexpression of Homer la, both of which result in a disconnection of Homer3 from mGluR, had similar effects (Fig. 2) (Ango et al., 2001). The hypothesis that BigK channels were overactivated, because of constitutive activation of mGluR after its release from the Homer3 network, was tested and confirmed. Indeed, inverse agonists of mGluR1a (BAY 36-7620) or mGluR5 (MPEP), but not competitive antagonists, were able to suppress this overactivation of BigK channels (Fig. 2) (Ango et al., 2001). We also showed that suppression of the coupling of mGluR to cross-linking Homers results in constitutive activation of inositol phosphate formation, which should result in an increase in intracellular $\mathrm{Ca}^{2+}$ release (Ango et al., 
2001). The constitutive activity of the Group I mGluR-Homerla complex has been largely confirmed (J. H. Hu et al., 2010; Diering et al., 2017; Chokshi et al., 2019b; Holz et al., 2019).

Similarly, it was shown that disconnection of TRPC from the Homer network by Homerla results in constitutive activation of TRPC (Yuan et al., 2003) (Fig. 1). The constitutive activation of Group I mGluR and TRPC suggests that Homerla accumulation in the spine tends to increase the level of $\mathrm{Ca}^{2+}$. The disconnection of RyRs (particularly RyR2) from L-type VSCC $\left(\mathrm{Ca}_{\mathrm{V}} 1.2\right)$ by Homerla also increases calcium elevation resulting from membrane depolarization, as well as the efficiency of calcium-induced calcium release (Huang et al., 2007; Worley et al., 2007).

These and other results (Worley et al., 2007; Clifton et al., 2019) indicate that cross-linking Homers buffer the intensity of basal $\mathrm{Ca}^{2+}$ signals in excitable (but also in nonexcitable) cells and that Homerla reverses this process. Calcium in spines is decisive for spike timing-dependent synaptic plasticity and the direction of changes in synaptic strength (Kampa et al., 2006). Thus, it is not surprising that Homerla contributes to synaptic plasticity (Luscher and Huber, 2010). Another effect of the constitutively active Group I mGluR-Homerla complex is activation of the mTOR pathway known to increase protein synthesis, including synthesis of synaptic proteins, such as AMPARs (W. Guo et al., 2016; Holz et al., 2019; Bouquier et al., 2020) (see Figs. $1,5)$. In conclusion, one is expecting that the profound remodeling of spine signaling, by Homerla, will have important physiological implications.

The crosstalk between Group I mGluR and NMDARs has been thoroughly investigated. Both positive and negative effects of Group I mGluR on NMDA current were reported depending on the neuronal cells investigated and protocol used (Fitzjohn et al., 1996; Yu et al., 1997; Awad et al., 2000; O’Neill et al., 2018). In the scope of this review, one particularly interesting crosstalk concerns the effects of the Group I mGluR-Homerla complex on NMDAR activity. Indeed, we have shown that Group I mGluR-Homerla strongly inhibited NMDARs (Perroy et al., 2008; Bertaso et al., 2010). We have shown, using bioluminescence resonance energy transfer technology, a direct interaction between mGluRs and NMDARs (Moutin et al., 2012). It is generally accepted that Group I mGluRs are localized at the edge of spines, whereas NMDARs are localized within the synaptic cleft (Shigemoto et al., 1993; Nusser et al., 1994). However, combining single-molecule super-resolution microscopy, electrophysiology, and modeling, it has been shown recently that mGluR5 is homogeneously dispersed at the postsynaptic membrane (Goncalves et al., 2020). $\mathrm{Ca}^{2+}$ entry through NMDARs activates CamKII, which can phosphorylate cross-linking Homers, reducing their interaction with mGlu5 (W. Guo et al., 2015). In this condition, the expression of Homerla induced by neuronal activity competes favorably with the cross-linking Homers for binding to the mGlu5 receptor (Moutin et al., 2012). Released from the ShankGKAP-PSD-95 complex, the mGlu5-Homerla complex directly binds to and inhibits NMDARs. Similarly, Homerla has been shown to decrease NMDA and AMPA membrane-associated receptors and currents, PSD-95 clusters, and spine density and size (Sala et al., 2003). The inhibition of NMDARs induced by the Group I mGluR-Homerla complex likely explains the inhibition of LTP following overexpression of Homerla (J. H. Hu et al., 2010; Rozov et al., 2012). Indeed, inhibition of NMDA currents results in an inhibition of AMPAR accumulation within postsynaptic membranes due in part to reduced tyrosine phosphorylation of the GluA1/GluA2 subunit (J. H. Hu et al., 2010; Diering et al., 2017). Reciprocally, deleting either the Homer1 gene or the short Homerl isoform results in an upregulation of postsynaptic AMPARs and currents (J. H. Hu et al., 2010; Rozov et al., 2012). Those effects of Group I mGluR-Homerla complex on ionotropic glutamate receptors are further amplified by the increase of Group I mGluR traffic to the plasma membrane. Indeed, a pool of Group I mGluR associated with cross-linking Homers is retained in the endoplasmic reticulum (Brakeman et al., 1997; Roche et al., 1999; Ango et al., 2000, 2002; Okada et al., 2009). The induction of Homerla through neuronal excitation interrupts this retention (Ango et al., 2002), permitting mGluR trafficking to the plasma membrane.

There are also conditions in which the constitutive activation of Group I mGluR by Homerla can lead to an increase in glutamate synaptic transmission. One potential mechanism involved in this increase is a coincident binding of Homerla to the Homer ligand domain once phosphorylated by kinases that target proline-adjacent serine or threonine (proline-directed kinases [PDKs]), such as Cdk5 and ERK (Orlando et al., 2009; J. H. Hu et al., 2012; Park et al., 2013). The phosphorylation of the Homer ligand by PDK is a complex mechanism. Group I mGluRs and PDKs are first assembled by an anchoring protein called FRMPD4/Preso1 forming a microdomain. FRMPD4/Preso1 is a multidomain protein containing a FERM domain that binds cytoplasmic tails of Group I mGluR, a Homer binding domain, and a C-terminal PDZ-binding-ligand that interacts with PSD95 (H. W. Lee et al., 2008; J. H. Hu et al., 2012; Wang et al., 2020). FRMPD4/Presol is crucial for the formation of excitatory synapses and dendritic spines and for physiological regulation of synaptic mGluR (H. W. Lee et al., 2008). Consistent with this, genetic studies have identified several mutations of FRMPD4 in patients with X-linked intellectual disability (Piton et al., 2013; H. Hu et al., 2016; Piard et al., 2018) and FRMPD4 KO mice displayed deficits in hippocampal spatial and learning memory (Piard et al., 2018). Once phosphorylated by PDK, mostly on the Serine 1126 (TPPpS1126-PF), the affinity of mGluR-Homer ligand for the Homers EVH1 domain is increased (Park et al., 2013). Phosphorylated Homer ligand associated with cross-linking Homers cannot bind another important protein (i.e., the prolyl isomerase [PIN1]). It is only when Homerla expression level is sufficiently high to displace cross-linking Homers from the phosphorylated Homer ligand of mGluR that PIN1 can bind and accelerate isomerization of the pS1126-P bond by more than a thousand-fold (Park et al., 2013). This creates a cis conformation of the pS1126-P bond, forming a tight hairpin turn between phenylalanine and the N-terminus of the Homer ligand (Fig. 3). Thus, when Group I mGluRs are associated with Homerla, phosphorylated by Cdk5 or ERK (e.g., after cocaine intake, BDNF stimulation of TrkB, or activation of Group I mGluR themselves), a particular structure of their C-terminal is stabilized. There is evidence that this particular mGluR conformation activates NMDARs and thus induces membrane accumulation of AMPARs (Park et al., 2013; Marton et al., 2015).

In conclusion, following CDK-induced phosphorylation of the Homer ligand of mGluR and its isomerization by PIN, the Group I mGluR-Homerla complex is no longer inhibiting, but rather is activating, NMDARs (Marton et al., 2015).

\section{Constitutively active Group I mGluR-Homerla complex is involved in metaplasticity and homeostatic synaptic scaling} Hebbian LTP and LTD induce rapid changes of the strength of specific synapses. These bidirectional activity-dependent modifications of excitatory synaptic strength are essential for learning and storage of new memories. NMDAR activation is required for 

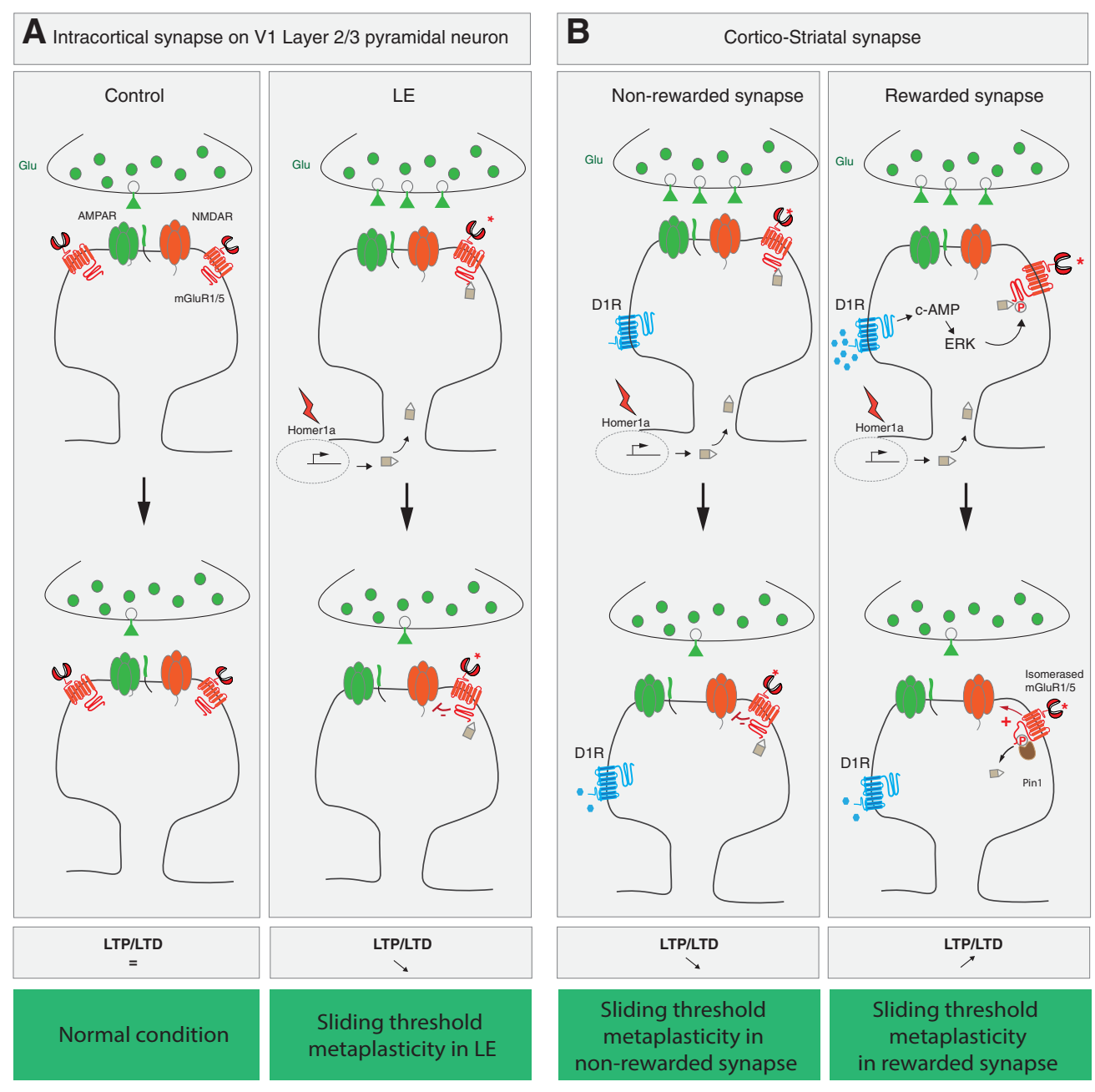

Figure 3. Sliding threshold metaplasticity in the visual system and in cortico-striatal excitatory rewarded and unrewarded synapses. A, Synapses between lateral intracortical neurons and V1 layer 2/3 (L2/3) pyramidal neurons. When a DE is reversed by an LE, sliding homeostatic plasticity occurs. Newly synthetized Homer1a constitutively activates mGluR5, which inhibits NMDARs through a direct interaction (Chokshi et al., 2019b). This leads to an increase in the threshold required for LTP induction. B, Cortico-striatal synapses. Two types of sliding homeostatic plasticity occur. In the absence of D1 dopamine receptor stimulation, activation of these synapses (unrewarded synapses) triggers, in downstream striatal neurons, similar signaling events as we have seen above in the visual system after LE. A decrease in the LTP/LTD ratio is observed. In contrast, when D1 receptors are activated before activation of the cortico-striatal synapses (rewarded synapses), Homer1a is synthetized constitutively and activates mGluR5. In addition, the D1 receptor-CAMP-ERK activated pathway allows the phosphorylation and isomerization (by PIN) of mGluR5. The phosphorylated and isomerized mGluRs activate (instead of inhibiting) NMDARs by an unknown mechanism, leading to an increase in the LTP/LTD ratio (Marton et al., 2015). *The mGluR1,5 receptors are constitutively activated.

these forms of plasticity (Huganir and Nicoll, 2013), but Group I mGluRs are also implicated, via different molecular mechanisms, in both LTD (Luscher and Huber, 2010) and LTP (Wang et al., 2020).

Changes in synaptic activity also occur over longer timescales and are called "non-Hebbian neuronal plasticity." The two main forms of non-Hebbian plasticity include "sliding threshold metaplasticity" and "homeostatic synaptic scaling" (Ibata et al., 2008; H. K. Lee and Kirkwood, 2019). Sliding threshold metaplasticity involves a change in the threshold needed for LTP induction, which depends on the past neuronal activity. For example, a decrease in overall activity (e.g., during visual deprivation) decreases the induction threshold for LTP because of an upregulation of synaptic expression of GluN2B-containing NMDARs. In contrast, an increase in activity (e.g., after rapid exposure to light after visual deprivation) increases the threshold for LTP, favoring LTD. This can be obtained by reducing synaptic expression of GluN2B-containing NMDARs (H. K. Lee and Kirkwood, 2019). Homeostatic synaptic scaling changes the overall activity level of neuronal network while maintaining the relative strengths of synapses by effectively scaling up or down the strengths of all synapses by the same multiplicative factor. This is generally produced by a change in AMPAR activity, without altering NMDAR activity (H. K. Lee and Kirkwood, 2019). During the last 10 years, it has been shown that the Group I mGluR-Homerla complex is a central component of both forms of non-Hebbian plasticity.

\section{Sliding threshold metaplasticity plasticity in the visual system}

Experience-dependent metaplasticity mechanisms in vivo have been widely studied in the mouse visual system (Whitt et al., 2014). For example, in juvenile mice, a few days of visual deprivation (dark experience $[\mathrm{DE}]$ ) results in upregulation of GluN2B-containing NMDARs in primary visual cortex, which promotes LTP in layer L2/3 pyramidal neuron of V1 (i.e., a sliding threshold metaplasticity) In V1 layer 2/3 (L2/3) pyramidal neurons that receive inputs from lateral intracortical neurons, a sliding threshold favoring LTD is observed when DE is reversed by reexposure to light (light experience [LE]; Fig. 3) (Philpot et al., 2003; Y. Guo et al., 2012; Petrus et al., 2015; Bridi et al., 
2018). This LE-induced visual metaplasticity involves NMDA and mGluR5 receptors and is associated with rapid induction of Homerla synthesis (Chokshi et al., 2019b). Genetic KO of Homerla (H1aKO) suppresses the LE-induced metaplasticity (Chokshi et al., 2019b). The interaction between mGluR5 and Homerla is necessary for this LE-induced homeostatic plasticity since it is absent in knock-in mice in which the mGluR5 Homer ligand domain has been mutated (Chokshi et al., 2019b). Furthermore, MPEP, an inverse agonist of mGluR5 (but not an inverse agonist of mGluR1) suppresses LE-induced weakening of IC synapses. Thus, Chokshi et al. (2019b) propose that the constitutive activation of mGluR5 following its interaction with Homerla and the subsequent inhibition of NMDARs is involved in LE metaplasticity. In this hypothesis, the previously observed inhibition of NMDAR by constitutively active mGluR5Homerla complex (Perroy et al., 2008) is the likely molecular mechanism involved (Ango et al., 2001; Bertaso et al., 2010; Moutin et al., 2012).

Most neurons in V1 respond to inputs from both eyes, but show varying degrees of $\mathrm{p} * *$ nce toward one or the other eye. This is termed ocular dominance (OD). In rodents, V1 neurons exhibit a strong bias toward the contralateral eye. OD development depends largely on spontaneous activity (Rakic, 1976; Espinosa and Stryker, 2012). Notably, alterations in visual experience during early postnatal life (3-5 weeks postnatally) can shift OD patterns. During this critical period, monocular deprivation (MD) induces a shift in OD toward the open eye. Two periods are observed following MD. In the first period, a depression of the deprived eye response (2-3 d MD) through homosynaptic LTD mechanisms is observed (Dudek and Bear, 1992). In the second period (5-6 d MD), a homeostatic mechanism leads to the strengthening of open-eye responses. Using optical imaging of intrinsic signals in V1 neurons, $\mathrm{H} 1 \mathrm{aKO}$ mice, and a mouse model that has reduced Homer1 binding to mGluR5, Chokshi et al. (2019a) demonstrated that the mGluR5-Homerla complex is required for establishing the normal postnatal development of contralateral bias in V1 neurons and for the homeostatic plasticity allowing maintenance of OD during the longer period (5-6 d) of MD. In contrast, in H1aKO mice, the OD shift observed in short-term MD (2-3 d) was unchanged, suggesting that the initial phase of MD is not dependent on Homerla expression (Chokshi et al., 2019a).

\section{Sliding threshold metaplasticity in reward-related excitatory synapses}

Drug addiction is now believed to be a form of learning that occurs at synapses that are reinforced by reward. The important role of mGluR5 in behavioral responses to cocaine was first demonstrated in mGluR5 KO mice (Chiamulera et al., 2001). Cocaine-induced locomotion, cocaine motor sensitization, and cocaine self-administration are all reduced in these KO mice (Bird and Lawrence, 2009). After cocaine exposure, motor sensitization results from enhancement of cortical input to the striatum (Pascoli et al., 2011). This enhancement involves stimulation of both mGluR5 and dopamine D1 receptors (Marton et al., 2015).

D1 receptors enhance synaptic strength by reducing LTD of cortico-striatal synapses, thus favoring LTP (Centonze et al., 2006). Using a large series of transgenic mice, it has been shown that D1 receptors induce threshold metaplasticity depend on Homerla induction, mGluR5 phosphorylation, and PIN1induced isomerization of phosphorylated mGluR5 (Park et al., 2013; Marton et al., 2015). Marton et al. (2015) propose that the molecular mechanisms involved could be as follows (see Fig. 3). During high activity of some corticostriatal neurons, Homer 1a expression is induced in striatal neurons. It will take tens of minutes to synthesize enough Homerla to dissociate mGluR5 from cross-linking Homers (Marton et al., 2015). In synapses that do not receive dopamine (nonrewarded synapses), the constitutively active mGluR5 will inhibit NMDARs and induce an increase of the threshold for LTP, favoring LTD, on further synaptic activation (Fig. 3). In contrast, in rewarded synapses, D1 receptors activate ERK via the cAMP pathway, leading to phosphorylation of mGluR5. Activation of mTORC1 by the mGluR5Homerla complex further activates ERK via phosphorylation of DARPP-32 (Lin et al., 2021). This may create a positive feedback loop for the phosphorylation of mGluR5 by ERK. As we discussed earlier in this review, phosphorylated mGluR5 displaced from cross-linking Homers by Homerla, binds PIN1, and isomerizes. Isomerized mGluR5 activates (instead of inhibiting, as when nonphosphorylated) NMDARs (Park et al., 2013; Marton et al., 2015). This will reduce the threshold for homeostatic plasticity, blocking depotentiation on further synaptic activation (Marton et al., 2015). Thus, in corticostriatal synapses that have been active enough to accumulate Homerla, a cocaine-induced increase in D1 receptor stimulation introduces a bias toward potentiation (rewarded synapses) compared with synapses not exposed to cocaine (Fig. 3). This may occlude further plasticity of rewarded synapses. It has been recently reported that, in D1 receptor-containing synapses, persistent activation of mTORC1 occludes further dynamic D1 signaling and D1 receptor-mediated responses, such as dynamic gene expression, cortico-striatal plasticity synapses, and some behavioral responses, such as sociability (Lin et al., 2021).

\section{Homeostatic synaptic scaling in synaptic networks}

The first demonstration of an involvement of the Group I mGluR-Homerla complex in homeostatic synaptic scaling was reported by J. H. Hu et al. (2010). Studying the scaling down of synaptic networks in DIV 14 cortical neurons in culture chronically overactivated by a bicuculline treatment, J. H. Hu et al. (2010) observed that this treatment reduced the membrane level of AMPARs (GluA1 and GluA2/3). The unexpected finding was that the co-presence of mGluR1 and mGluR5 inverse agonists (Bay 36-7620 and MPEP, respectively), but not the co-presence of neutral antagonists of mGLuR5 and mGluR1 (CPCCOEt plus (S)-MCPG respectively), was able to inhibit this homeostatic downscaling of the network. One caveat is that inverse agonists have much higher affinity than neutral antagonists; and accordingly, the authors were using much higher concentrations (20100 times higher) of neutral antagonists than of inverse agonists.

In addition, J. H. Hu et al. (2010) showed that the hydrolysis of glutamate in the culture with glutamate pyruvate transaminase and sodium pyruvate did not modify the homeostatic downscaling after bicuculline treatment, excluding a role of endogenous glutamate in the activation of mGluR5 in the process. This strongly establishes that the downregulation of AMPARs requires a constitutively active form, and not a glutamate-activated form of mGluR1 and mGluR5. Furthermore, Homerla induction with Sindbis virus was sufficient to produce downscaling of the network independently of stimulation of Group I mGluR by glutamate, but blocked by mGluR inverse agonists (J. $\mathrm{H}$. Hu et al., 2010). It was further established that the Homerla constitutively active Group I mGluR complex reduces tyrosine phosphorylation of GluA2 receptors, which is implicated in their trafficking to synaptic membranes. This effect of Homerla on 


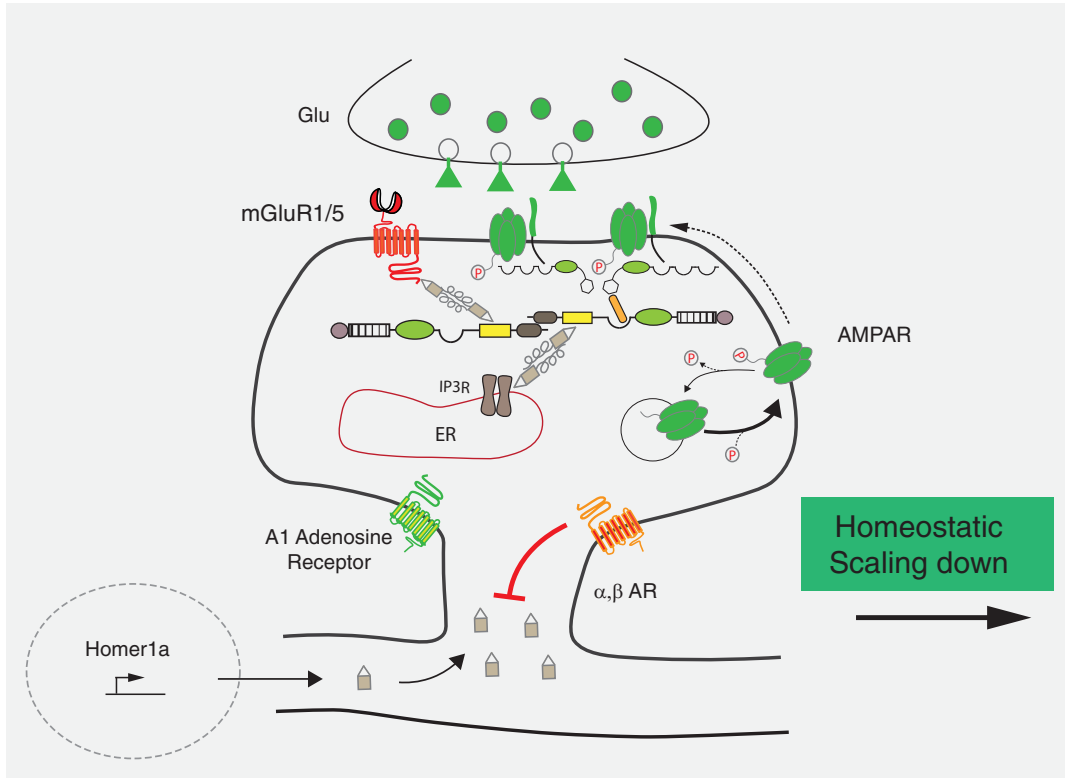

WAKE

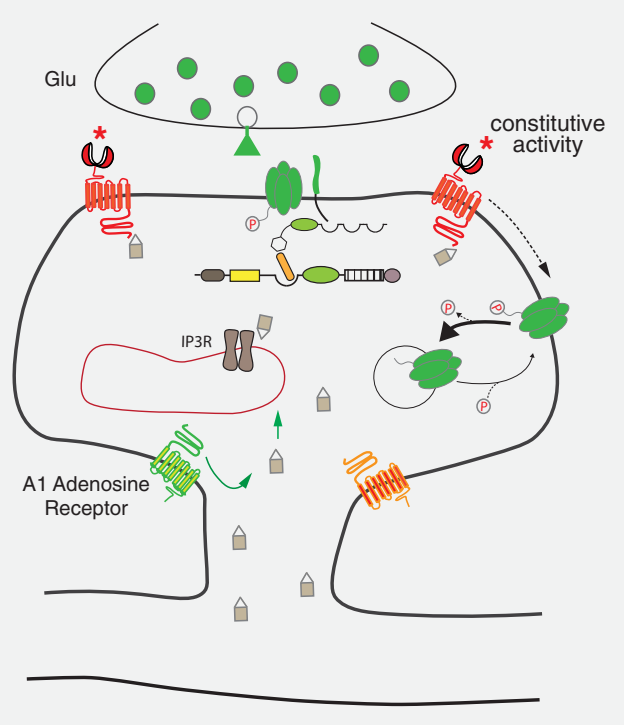

SLEEP

Figure 4. Homeostatic glutamatergic synaptic downscaling during sleep periods. During wake periods, cross-linking Homers are fully operational. Neuronal activity-induced Homer1a accumulates outside the dendritic spine because spine entry is blocked by $\alpha$-and $\beta$-activated adrenergic receptors via an unknown mechanism. During a sleep period, Homer1a entry into spine is facilitated by the activation of adenosine A1 receptors via an unknown mechanism. The constitutively active mGluR1,5-Homer1a complex increases the dephosphorylation of AMPARs. This induces homeostatic downscaling glutamatergic synapses. *The mGluR1,5 receptors are constitutively activated.

the phosphorylation of GluA2 was confirmed in vivo by showing GluA2 phosphorylation is enhanced in Homer1a $\mathrm{KO}$ mice (J. H. $\mathrm{Hu}$ et al., 2010). In conclusion, these results support a model in which constitutive activation of Group I mGluR, because of their association with Homer1a, results in reduced GluA2 tyrosine phosphorylation, leading to less GluA2 membrane insertion and consequently weakening of synaptic strength.

Homeostatic synaptic scaling of excitatory synapses during sleep Synapses undergo homeostatic downscaling during sleep (Diering et al., 2017). This may be important to increase the sig$\mathrm{nal} /$ noise ratio of synapses that underwent LTP during waking life and facilitate memory consolidation (Tononi and Cirelli, 2014). Adenosine is one of the neuromodulators that accumulates during waking and influences sleep induction (Wigren et al., 2007). During waking life, Homer la is synthetized, but its accumulation within the PSD is blocked by activation of $\alpha$ and $\beta$ adrenergic receptors (Fig. 4) (Diering et al., 2017). In contrast, during sleep, Homerla accumulates within the PSD, a process facilitated by adenosine acting on adenosine A1 receptors (Diering et al., 2017) (Fig. 4). The analysis of protein content of PSDs and two-photon imaging of wake/sleep synapses indicate that synapses contain less GluA1 and GluA2 AMPAR subunits during sleep. In addition, these synapses show decreased phosphorylation of GluA1 at S845 and S831, decreased levels of the PKA catalytic unit and AKAP 50, and decreased levels of mGluR5, PKC, and IP3-Rs (Diering et al., 2017). All these modifications are absent in Homerla KO mice. Blocking mGluR5 with the inverse agonist MPEP during sleep induces a low but significant increase in GluAl expression. Thus, Diering et al. (2017) propose that, during waking life and learning, Homerla is synthetized but excluded from spines by adrenergic receptor activation. During sleep induction, characterized by a decrease in noradrenaline and an increase in adenosine, Homerla is targeted to the synapses, and interacts with mGluR5. Constitutive activation of mGluR5 remodels the signaling pathways, induces a scaling down of synapses by decreasing AMPAR phosphorylation, and therefore decreases AMPAR membrane insertion (Fig. 4). Whether the constitutive activation of mGluR5 also inhibits NMDAR activity during sleep, as expected, has not been studied. The roles of Homerla and mGluR in sleep properties in different species have been reported. Genetic deletion of the unique ortho$\log$ of Homer in Drosophila results in fragmented sleep and an incapacity to undergo long bouts of sleep even under sleep deprivation (SD) (Naidoo et al., 2012). In addition, genetic disruption of the putative binding site for Homer on DmGluRA, the unique mGluR in Drosophila (Parmentier et al., 1996), reduces sleep (Ly et al., 2020).

In mice, a polymorphism of the Homerla gene is associated with sleep drive (Mackiewicz et al., 2008). H1aKO mice show reduced wakefulness with an inability to sustain long bouts of wakefulness active periods (dark periods) and display a modest change in circadian period (Naidoo et al., 2012).

A study in the Brazilian population suggests that the rs3822568 polymorphism in the Homer gene might have an impact on sleep quality and sleep structure. People carrying this mutation showed higher sleep latency, lower sleep efficiency, reduced number of arousals per hour, lower apnea-hypopnea index, and lower theta spectral power than GG genotyped individuals (Pedrazzoli et al., 2020). In the latter two studies, the involvement of Group I mGluR was not established.

Homeostatic synaptic scaling of excitatory synapses during SD and other antidepressant treatments

It has been shown that the antidepressant effects of SD, imipramine, ketamine, electroconvulsive treatment, repetitive transcranial 


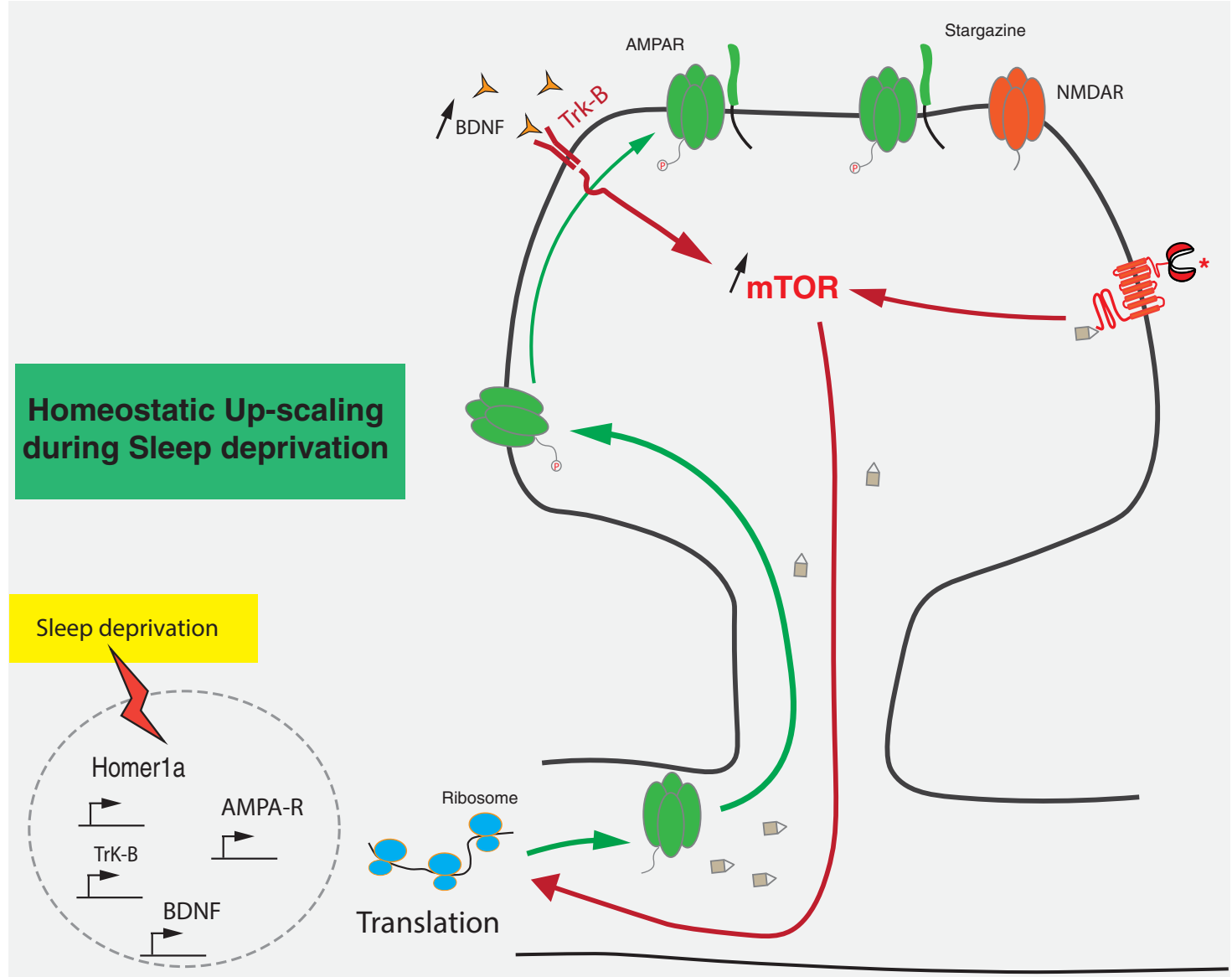

Figure 5. Homeostatic mPFC glutamatergic synaptic upscaling during SD: an antidepressant treatment. The molecular mechanisms by which SD modifies mPFC excitatory synapses have been recently deciphered, at least in part (Holz et al., 2019). A Tat-Homer1a cell-permeable peptide, disconnecting mGluR5 from cross-linking Homer, mimics the signaling pathways and antidepressant effect of SD. This peptide and SD activate mTOR signaling and AMPAR translation, a key step in antidepressant therapeutic effect. These signaling events are triggered by the constitutive mGluR5-Homer1a complex because they are blocked by MPEP, an inverse agonist of mGluR5. mTOR is also activated by TrkB. *The mGluR1,5 receptors are constitutively activated.

magnetic stimulation, and photic stimulation involved Homerla (Sakagami et al., 2005; Yamamoto et al., 2011; Serchov et al., 2015; Sun et al., 2015; van Calker et al., 2018; Holz et al., 2019). Knock-in mice with an mGluR Homer ligand mutation that abrogates binding to cross-linking Homers have an antidepressant phenotype (W. Guo et al., 2016). Silencing the Homerla gene with small interfering RNA increases depressive-like behavior and blunts the antidepressant action of SD, imipramine, or ketamine (Serchov et al., 2015). In addition to Homerla transcription, most of these antidepressant therapies, including SD (Schmitt et al., 2016), involve transcriptional regulation of $\mathrm{BDNF}$ and $\operatorname{TrkB}$, and thus Trk B stimulation (van Calker et al., 2018). An upregulation of AMPAR density and activity is also associated with antidepressant effect of BDNF (Fortin et al., 2012; van Calker et al., 2018). Since AMPAR activation increases BDNF, a virtuous circle may be on board.

It is thus possible that long-lasting upregulation of AMPARs at glutamatergic synapses within $\mathrm{MPFC}$ is a common component of all antidepressant treatments (Duman et al., 2016). This is the definition of homeostatic upscaling of excitatory synapses. In other words, antidepressants, by upregulating AMPAR expression of the mPFC glutamatergic synapses, should increase the overall neuronal network activity while maintaining the relative strengths of synapses. The mechanisms by which all those treatments converge to homeostatic upscaling is not clear, but Homerla may be central since almost all antidepressant treatments upregulate Homerla (van Calker et al., 2018).
Recently, it has been shown that TAT-Homerla, a membrane-permeable derivative of Homerla, has antidepressant action (Holz et al., 2019). Not surprising for us, TAT-Homerla, like SD, constitutively activates mGluR5, specifically in excitatory CaMK2a neurons, increases mTOR pathway activity and finally the translation and synaptic expression of GluAl (Holz et al., 2019) (Fig. 5). These effects are blocked by MPEP, an mGluR5 inverse agonist (Holz et al., 2019). Trk-B receptors may also act, in synergy with mGluR5-Homerla, to overactivate mTOR (Duman et al., 2012).

The mGluR5-Homerla complex induces homeostatic upscaling of excitatory synapses following SD, whereas it has an opposite effect during normal sleep (Diering et al., 2017).

However, during normal sleep, Homerla is not synthetized, but it is only its traffic within spines that is increased (Diering et al., 2017). It is possible that, during SD, the activation of mTOR and ERK and thus AMPAR synthesis is so high that the dephosphorylation and endocytosis of AMPARs induced by the mGluR5-Homerla complex, as seen during normal sleep (Diering et al., 2017), became negligible.

\section{Conclusion}

The possibility of activating GPCRs by intracellular proteins in addition to their classical stimulation by extracellular ligands has only recently been recognized (Ango et al., 2002; Bockaert et al., 
2010; Duhr et al., 2014; Chaumont-Dubel et al., 2020; Pujol et al., 2020). A major difference between GPCR activation by extracellular ligands or by intracellular proteins is the timing. The action of extracellular ligands is fast (100 ms to minutes) and rapidly reversible. Activating GPCRs by intracellular proteins is a slow process depending on protein turnover. Some are only synthetized following particular events. This is the case for products of immediate early genes, such as Homerla. The activation of Group I mGluR by Homerla occurs after neural excitation of diverse sources, which take tens of minutes and last until Homerla is degraded (hours). Therefore, it is not surprising that constitutive activation of Group I mGluR by Homerla has been selected as a key mechanism for inducing long-lasting nonHebbian synaptic plasticity "Sliding threshold metaplasticity" and "Homeostatic synaptic scaling."

The Group I mGluR-Homerla complex increases the threshold for LTP induction in some synapses by the molecular mechanism that we described 20 years ago. Homerla induces disconnection of Group I mGluR from cross-linking Homers, which leads to allosteric constitutive activation of mGluR1 or 5, which in turn inhibit NMDARs and therefore increase the threshold for LTP induction (Ango et al., 2001; Perroy et al., 2008). This metaplasticity has been described in V1 layer $2 / 3$ (L2/3) pyramidal neuron synapses receiving inputs from lateral intracortical neurons when a DE is reversed by reexposure to light (LE) (Chokshi et al., 2019b). It is also present in corticostriatal synapses that do not receive a coincident dopaminergic input (nonrewarded synapses) (Marton et al., 2015). However, in corticostriatal synapses receiving D1 input (following cocaine intake) in advance (rewarded synapses), a decrease in threshold for LTP induction is observed. Here, the "past" of synaptic state includes a modulation of NMDAR activity by D1 receptors. The mGluR5-Homerla complex is again involved. However, there is a coincident phosphorylation of the mGluR5 receptors by the D1/cAMP/ERK pathway followed by their isomerization by the prolyl isomerase PIN1. The result is an activation of NMDARs by the phosphorylated mGluR5 receptors (via an unknown mechanism) and a bias toward potentiation of those synapses (Park et al., 2013; Marton et al., 2015).

Another type of non-Hebbian plasticity in which the Group I mGluR-Homerla complex is involved is homeostatic synaptic scaling. During synaptic network overstimulation (J. H. Hu et al., 2010) and during sleep (Diering et al., 2017), the constitutive activation of mGluR1 or 5 by Homerla results in a scaling down of synapses via a decrease in AMPAR phosphorylation, and thus a decrease in synaptic AMPAR concentration.

It is intriguing that scaling up homeostatic synaptic plasticity observed during SD, known to induce antidepressant effects, also involves the mGluR5-Homerla complex. Here, high activation of the mTOR pathway by the mGluR5-Homerla complex, followed by translational synthesis of new AMPARs is involved (Holz et al., 2019). BDNF activation of the mTOR pathway during SD may also contribute to this enhancement of AMPA (Schmitt et al., 2016).

It is highly probable that there exist other physiological and pathologic situations in which the constitutively active Group I-mGluR-homerla complex is implicated. This includes neuroprotection against traumatic brain injury, enhancement of contextual fear (Tronson et al., 2010); obsessive-compulsive disorder-like behavior in mice in which GKAP (Sapap3) has been knocked out (Ade et al., 2016); and finally, some forms of autism spectrum disorders, such as fragile X syndrome (W. Guo et al., 2015, 2016).

\section{References}

Ade KK, Wan Y, Hamann HC, O'Hare JK, Guo W, Quian A, Kumar S, Bhagat S, Rodriguiz RM, Wetsel WC, Conn PJ, Dzirasa K, Huber KM, Calakos N (2016) Increased metabotropic glutamate receptor 5 signaling underlies obsessive-compulsive disorder-like behavioral and striatal circuit abnormalities in mice. Biol Psychiatry 80:522-533.

Ango F, Pin JP, Tu JC, Xiao B, Worley PF, Bockaert J, Fagni L (2000) Dendritic and axonal targeting of type 5 metabotropic glutamate receptor is regulated by homer1 proteins and neuronal excitation. J Neurosci 20:8710-8716

Ango F, Prezeau L, Muller T, Tu JC, Xiao B, Worley PF, Pin JP, Bockaert J, Fagni L (2001) Agonist-independent activation of metabotropic glutamate receptors by the intracellular protein Homer. Nature 411:962-965.

Ango F, Robbe D, Tu JC, Xiao B, Worley PF, Pin JP, Bockaert J, Fagni L (2002) Homer-dependent cell surface expression of metabotropic glutamate receptor type 5 in neurons. Mol Cell Neurosci 20:323-329.

Awad H, Hubert GW, Smith Y, Levey AI, Conn PJ (2000) Activation of metabotropic glutamate receptor 5 has direct excitatory effects and potentiates NMDA receptor currents in neurons of the subthalamic nucleus. J Neurosci 20:7871-7879.

Bertaso F, Roussignol G, Worley P, Bockaert J, Fagni L, Ango F (2010) Homerla-dependent crosstalk between NMDA and metabotropic glutamate receptors in mouse neurons. PLoS One 5:e9755.

Bezanilla F (2008) How membrane proteins sense voltage. Nat Rev Mol Cell Biol 9:323-332.

Bird MK, Lawrence AJ (2009) The promiscuous mGlu5 receptor: a range of partners for therapeutic possibilities? Trends Pharmacol Sci 30:617-623.

Bockaert J, Perroy J, Becamel C, Marin P, Fagni L (2010) GPCR interacting proteins (GIPs) in the nervous system: roles in physiology and pathologies. Annu Rev Pharmacol Toxicol 50:89-109.

Bottai D, Guzowski JF, Schwarz MK, Kang SH, Xiao B, Lanahan A, Worley PF, Seeburg PH (2002) Synaptic activity-induced conversion of intronic to exonic sequence in Homer 1 immediate early gene expression. J Neurosci 22:167-175.

Bouquier N, Moutin E, Tintignac LA, Reverbel A, Jublanc E, Sinnreich M, Chastagnier Y, Averous J, Fafournoux P, Verpelli C, Boeckers T, Carnac G, Perroy J, Ollendorff V (2020) AIMTOR, a BRET biosensor for live imaging, reveals subcellular mTOR signaling and dysfunctions. BMC Biol 18:81.

Brakeman PR, Lanahan AA, O’Brien R, Roche K, Barnes CA, Huganir RL, Worley PF (1997) Homer: a protein that selectively binds metabotropic glutamate receptors. Nature 386:284-288.

Bridi MC, de Pasquale R, Lantz CL, Gu Y, Borrell A, Choi SY, He K, Tran T, Hong SZ, Dykman A, Lee HK, Quinlan EM, Kirkwood A (2018) Two distinct mechanisms for experience-dependent homeostasis. Nat Neurosci 21:843-850.

Centonze D, Costa C, Rossi S, Prosperetti C, Pisani A, Usiello A, Bernardi G, Mercuri NB, Calabresi P (2006) Chronic cocaine prevents depotentiation at corticostriatal synapses. Biol Psychiatry 60:436-443.

Chan HC, Li Y, Dahoun T, Vogel H, Yuan S (2019) New binding sites, new opportunities for GPCR drug discovery. Trends Biochem Sci 44:312-330.

Chaumont-Dubel S, Dupuy V, Bockaert J, Bécamel C, Marin P (2020) The 5HT6 receptor interactome: new insight in receptor signaling and its impact on brain physiology and pathologies. Neuropharmacology 172:107839.

Chiamulera C, Epping-Jordan MP, Zocchi A, Marcon C, Cottiny C, Tacconi S, Corsi M, Orzi F, Conquet F (2001) Reinforcing and locomotor stimulant effects of cocaine are absent in mGluR5 null mutant mice. Nat Neurosci 4:873-874.

Chokshi V, Druciak B, Worley PF, Lee HK (2019a) Homerla is required for establishment of contralateral bias and maintenance of ocular dominance in mouse visual cortex. J Neurosci 39:3897-3905.

Chokshi V, Gao M, Grier BD, Owens A, Wang H, Worley PF, Lee HK (2019b) Input-specific metaplasticity in the visual cortex requires Homer1a-mediated mGluR5 signaling. Neuron 104:736-748.e736.

Christopoulos A, Kenakin T (2002) G protein-coupled receptor allosterism and complexing. Pharmacol Rev 54:323-374.

Clifton NE, Trent S, Thomas KL, Hall J (2019) Regulation and function of activity-dependent Homer in synaptic plasticity. Mol Neuropsychiatry 5:147-161. 
Delcourt N, Bockaert J, Marin P (2007) GPCR-jacking: from a new route in RTK signalling to a new concept in GPCR activation. Trends Pharmacol Sci 28:602-607.

Deraredj Nadim W, Chaumont-Dubel S, Madouri F, Cobret L, De Tauzia ML, Zajdel P, Bénédetti H, Marin P, Morisset-Lopez S (2016) Physical interaction between neurofibromin and serotonin 5-HT6 receptor promotes receptor constitutive activity. Proc Natl Acad Sci USA 113:1231012315.

Diering GH, Nirujogi RS, Roth RH, Worley PF, Pandey A, Huganir RL (2017) Homerla drives homeostatic scaling-down of excitatory synapses during sleep. Science 355:511-515.

Du Y, Duc NM, Rasmussen SG, Hilger D, Kubiak X, Wang L, Bohon J, Kim HR, Wegrecki M, Asuru A, Jeong KM, Lee J, Chance MR, Lodowski DT, Kobilka BK, Chung KY (2019) Assembly of a GPCR-G protein complex. Cell 177:1232-1242.e211.

Dudek SM, Bear MF (1992) Homosynaptic long-term depression in area CA1 of hippocampus and effects of N-methyl-D-aspartate receptor blockade. Proc Natl Acad Sci USA 89:4363-4367.

Duhr F, Deleris P, Raynaud F, Seveno M, Morisset-Lopez S, Mannoury la Cour C, Millan MJ, Bockaert J, Marin P, Chaumont-Dubel S (2014) Cdk5 induces constitutive activation of 5-HT6 receptors to promote neurite growth. Nat Chem Biol 10:590-597.

Duman RS, Li N, Liu RJ, Duric V, Aghajanian G (2012) Signaling pathways underlying the rapid antidepressant actions of ketamine. Neuropharmacology 62:35-41.

Duman RS, Aghajanian GK, Sanacora G, Krystal JH (2016) Synaptic plasticity and depression: new insights from stress and rapid-acting antidepressants. Nat Med 22:238-249.

Espinosa JS, Stryker MP (2012) Development and plasticity of the primary visual cortex. Neuron 75:230-249.

Fagni L, Ango F, Perroy J, Bockaert J (2004) Identification and functional roles of metabotropic glutamate receptor-interacting proteins. Semin Cell Dev Biol 15:289-298.

Fagni L, Worley PF, Ango F (2002) Homer as both a scaffold and transduction molecule. Sci STKE 2002:re8.

Fitzjohn SM, Irving AJ, Palmer MJ, Harvey J, Lodge D, Collingridge GL (1996) Activation of group I mGluRs potentiates NMDA responses in rat hippocampal slices. Neurosci Lett 203:211-213.

Fortin DA, Srivastava T, Dwarakanath D, Pierre P, Nygaard S, Derkach VA, Soderling TR (2012) Brain-derived neurotrophic factor activation of CaM-kinase kinase via transient receptor potential canonical channels induces the translation and synaptic incorporation of GluA1-containing calcium-permeable AMPA receptors. J Neurosci 32:8127-8137.

Goncalves J, Bartol TM, Camus C, Levet F, Menegolla AP, Sejnowski TJ, Sibarita JB, Vivaudou M, Choquet D, Hosy E (2020) Nanoscale co-organization and coactivation of AMPAR, NMDAR, and mGluR at excitatory synapses. Proc Natl Acad Sci USA 117:14503-14511.

Gray NW, Fourgeaud L, Huang B, Chen J, Cao H, Oswald BJ, Hemar A, McNiven MA (2003) Dynamin 3 is a component of the postsynapse, where it interacts with mGluR5 and Homer. Curr Biol 13:510-515.

Guo W, Ceolin L, Collins KA, Perroy J, Huber KM (2015) Elevated CaMKIIalpha and hyperphosphorylation of Homer mediate circuit dysfunction in a Fragile X syndrome mouse model. Cell Rep 13:2297-2311.

Guo W, Molinaro G, Collins KA, Hays SA, Paylor R, Worley PF, Szumlinski KK, Huber KM (2016) Selective disruption of metabotropic glutamate receptor 5-Homer interactions mimics phenotypes of Fragile X syndrome in mice. J Neurosci 36:2131-2147.

Guo Y, Huang S, de Pasquale R, McGehrin K, Lee HK, Zhao K, Kirkwood A (2012) Dark exposure extends the integration window for spike-timingdependent plasticity. J Neurosci 32:15027-15035.

Hayashi MK, Ames HM, Hayashi Y (2006) Tetrameric hub structure of postsynaptic scaffolding protein homer. J Neurosci 26:8492-8501.

Hayashi MK, Tang C, Verpelli C, Narayanan R, Stearns MH, Xu RM, Li H, Sala C, Hayashi Y (2009) The postsynaptic density proteins Homer and Shank form a polymeric network structure. Cell 137:159-171.

Holz A, Mulsch F, Schwarz MK, Hollmann M, Dobrossy MD, Coenen VA, Bartos M, Normann C, Biber K, van Calker D, Serchov T (2019) Enhanced mGlu 5 signaling in excitatory neurons promotes rapid antidepressant effects via AMPA receptor activation. Neuron 104:338-352. e337.

Hu H, Haas SA, Chelly J, Van Esch H, Raynaud M, de Brouwer AP, Weinert S, Froyen G, Frints SG, Laumonnier F, Zemojtel T, Love MI, Richard H,
Emde AK, Bienek M, Jensen C, Hambrock M, Fischer U, Langnick C, Feldkamp M, et al. (2016) X-exome sequencing of 405 unresolved families identifies seven novel intellectual disability genes. Mol Psychiatry 21:133-148.

Hu JH, Park JM, Park S, Xiao B, Dehoff MH, Kim S, Hayashi T, Schwarz MK, Huganir RL, Seeburg PH, Linden DJ, Worley PF (2010) Homeostatic scaling requires group I mGluR activation mediated by Homerla. Neuron 68:1128-1142.

Hu JH, Yang L, Kammermeier PJ, Moore CG, Brakeman PR, Tu J, Yu S, Petralia RS, Li Z, Zhang PW, Park JM, Dong X, Xiao B, Worley PF (2012) Presol dynamically regulates group I metabotropic glutamate receptors. Nat Neurosci 15:836-844.

Huang G, Kim JY, Dehoff M, Mizuno Y, Kamm KE, Worley PF, Muallem S, Zeng W (2007) $\mathrm{Ca}^{2+}$ signaling in microdomains: homerl mediates the interaction between RyR2 and Cav1.2 to regulate excitation-contraction coupling. J Biol Chem 282:14283-14290.

Huganir RL, Nicoll RA (2013) AMPARs and synaptic plasticity: the last 25 years. Neuron 80:704-717.

Ibata K, Sun Q, Turrigiano GG (2008) Rapid synaptic scaling induced by changes in postsynaptic firing. Neuron 57:819-826.

Kammermeier PJ, Xiao B, Tu JC, Worley PF, Ikeda SR (2000) Homer proteins regulate coupling of group I metabotropic glutamate receptors to N-type calcium and M-type potassium channels. J Neurosci 20:72387245.

Kampa BM, Letzkus JJ, Stuart GJ (2006) Requirement of dendritic calcium spikes for induction of spike-timing-dependent synaptic plasticity. J Physiol 574:283-290.

Karaki S, Becamel C, Murat S, Mannoury la Cour C, Millan MJ, Prezeau L, Bockaert J, Marin P, Vandermoere F (2014) Quantitative phosphoproteomics unravels biased phosphorylation of serotonin 2A receptor at Ser280 by hallucinogenic versus nonhallucinogenic agonists. Mol Cell Proteomics 13:1273-1285.

Kato A, Ozawa F, Saitoh Y, Fukazawa Y, Sugiyama H, Inokuchi K (1998) Novel members of the Vesl/Homer family of PDZ proteins that bind metabotropic glutamate receptors. J Biol Chem 273:23969-23975.

Kim E, Sheng M (2004) PDZ domain proteins of synapses. Nat Rev Neurosci 5:771-781.

Kursula P (2019) Shanks: multidomain molecular scaffolds of the postsynaptic density. Curr Opin Struct Biol 54:122-128.

Lee HK, Kirkwood A (2019) Mechanisms of homeostatic synaptic plasticity in vivo. Front Cell Neurosci 13:520.

Lee HW, Choi J, Shin H, Kim K, Yang J, Na M, Choi SY, Kang GB, Eom SH, Kim H, Kim E (2008) Preso, a novel PSD-95-interacting FERM and PDZ domain protein that regulates dendritic spine morphogenesis. J Neurosci 28:14546-14556.

Lefkowitz RJ, Cotecchia S, Samama P, Costa T (1993) Constitutive activity of receptors coupled to guanine nucleotide regulatory proteins. Trends Pharmacol Sci 14:303-307.

Li Y, Krogh KA, Thayer SA (2012) Epileptic stimulus increases Homer 1a expression to modulate endocannabinoid signaling in cultured hippocampal neurons. Neuropharmacology 63:1140-1149.

Liggett SB (2011) Phosphorylation barcoding as a mechanism of directing GPCR signaling. Sci Signal 4:pe36.

Lin R, Learman LN, Na CH, Renuse S, Chen KT, Chen PY, Lee GH, Xiao B, Resnick SM, Troncoso JC, Szumlinski KK, Linden DJ, Park JM, Savonenko A, Pandey A, Worley PF (2021) Persistently elevated mTOR complex 1-S6 kinase 1 disrupts DARPP-32-dependent D1 dopamine receptor signaling and behaviors. Biol Psychiatry 89:1058-1072.

Liu X, Ahn S, Kahsai AW, Meng KC, Latorraca NR, Pani B, Venkatakrishnan AJ, Masoudi A, Weis WI, Dror RO, Chen X, Lefkowitz RJ, Kobilka BK (2017) Mechanism of intracellular allosteric beta2AR antagonist revealed by X-ray crystal structure. Nature 548:480-484.

Liu X, Masoudi A, Kahsai AW, Huang LY, Pani B, Staus DP, Shim PJ, Hirata K, Simhal RK, Schwalb AM, Rambarat PK, Ahn S, Lefkowitz RJ, Kobilka B (2019) Mechanism of beta2AR regulation by an intracellular positive allosteric modulator. Science 364:1283-1287.

Luo P, Chen T, Zhao Y, Zhang L, Yang Y, Liu W, Li S, Rao W, Dai S, Yang J, Fei Z (2014) Postsynaptic scaffold protein Homer 1a protects against traumatic brain injury via regulating group I metabotropic glutamate receptors. Cell Death Dis 5:e1174. 
Luscher C, Huber KM (2010) Group 1 mGluR-dependent synaptic longterm depression: mechanisms and implications for circuitry and disease. Neuron 65:445-459.

Luttrell LM, Maudsley S, Bohn LM (2015) Fulfilling the promise of 'biased' G protein-coupled receptor agonism. Mol Pharmacol 88:579-588.

Ly S, Strus E, Naidoo N (2020) Genetic disruption of the putative binding site for Homer on DmGluRA reduces sleep in Drosophila. Sleep 43: zsz190.

Mackiewicz M, Paigen B, Naidoo N, Pack AI (2008) Analysis of the QTL for sleep homeostasis in mice: homerla is a likely candidate. Physiol Genomics 33:91-99.

Mahan AL, Mou L, Shah N, Hu JH, Worley PF, Ressler KJ (2012) Epigenetic modulation of Homerla transcription regulation in amygdala and hippocampus with pavlovian fear conditioning. J Neurosci 32:4651-4659.

Marton TM, Hussain Shuler MG, Worley PF (2015) Homer 1a and mGluR5 phosphorylation in reward-sensitive metaplasticity: a hypothesis of neuronal selection and bidirectional synaptic plasticity. Brain Res 1628:1728.

Miller WE, Houtz DA, Nelson CD, Kolattukudy PE, Lefkowitz RJ (2003) Gprotein-coupled receptor (GPCR) kinase phosphorylation and betaarrestin recruitment regulate the constitutive signaling activity of the human cytomegalovirus US28 GPCR. J Biol Chem 278:21663-21671.

Miyabe T, Miletic G, Miletic V (2006) Loose ligation of the sciatic nerve in rats elicits transient upregulation of Homerla gene expression in the spinal dorsal horn. Neurosci Lett 398:296-299.

Moutin E, Raynaud F, Roger J, Pellegrino E, Homburger V, Bertaso F, Ollendorff V, Bockaert J, Fagni L, Perroy J (2012) Dynamic remodeling of scaffold interactions in dendritic spines controls synaptic excitability. J Cell Biol 198:251-263.

Murat S, Bigot M, Chapron J, Konig GM, Kostenis E, Battaglia G, Nicoletti F, Bourinet E, Bockaert J, Marin P, Vandermoere F (2019) 5-HT2A receptor-dependent phosphorylation of mGlu2 receptor at Serine 843 promotes mGlu2 receptor-operated Gi/o signaling. Mol Psychiatry 24:16101626.

Naidoo N, Ferber M, Galante RJ, McShane B, Hu JH, Zimmerman J, Maislin G, Cater J, Wyner A, Worley P, Pack AI (2012) Role of Homer proteins in the maintenance of sleep-wake states. PLoS One 7:e35174.

Nobles KN, Xiao K, Ahn S, Shukla AK, Lam CM, Rajagopal S, Strachan RT, Huang TY, Bressler EA, Hara MR, Shenoy SK, Gygi SP, Lefkowitz RJ (2011) Distinct phosphorylation sites on the beta(2)-adrenergic receptor establish a barcode that encodes differential functions of beta-arrestin. Sci Signal 4:ra51.

Nusser Z, Mulvihill E, Streit P, Somogyi P (1994) Subsynaptic segregation of metabotropic and ionotropic glutamate receptors as revealed by immunogold localization. Neuroscience 61:421-427.

Nygaard R, Zou Y, Dror RO, Mildorf TJ, Arlow DH, Manglik A, Pan AC, Liu CW, Fung JJ, Bokoch MP, Thian FS, Kobilka TS, Shaw DE, Mueller L, Prosser RS, Kobilka BK (2013) The dynamic process of beta(2)-adrenergic receptor activation. Cell 152:532-542.

O'Neill N, McLaughlin C, Komiyama N, Sylantyev S (2018) Biphasic modulation of NMDA receptor function by metabotropic glutamate receptors. J Neurosci 38:9840-9855.

Okada D, Ozawa F, Inokuchi K (2009) Input-specific spine entry of somaderived Vesl-1S protein conforms to synaptic tagging. Science 324:904909.

Orlando LR, Ayala R, Kett LR, Curley AA, Duffner J, Bragg DC, Tsai LH, Dunah AW, Young AB (2009) Phosphorylation of the homer-binding domain of group I metabotropic glutamate receptors by cyclin-dependent kinase 5. J Neurochem 110:557-569.

Oswald C, Rappas M, Kean J, Dore AS, Errey JC, Bennett K, Deflorian F, Christopher JA, Jazayeri A, Mason JS, Congreve M, Cooke RM, Marshall $\mathrm{FH}$ (2016) Intracellular allosteric antagonism of the CCR9 receptor. Nature 540:462-465.

Park JM, Hu JH, Milshteyn A, Zhang PW, Moore CG, Park S, Datko MC, Domingo RD, Reyes CM, Wang XJ, Etzkorn FA, Xiao B, Szumlinski KK, Kern D, Linden DJ, Worley PF (2013) A prolyl-isomerase mediates dopamine-dependent plasticity and cocaine motor sensitization. Cell 154:637650.

Parmentier ML, Pin JP, Bockaert J, Grau Y (1996) Cloning and functional expression of a Drosophila metabotropic glutamate receptor expressed in the embryonic CNS. J Neurosci 16:6687-6694.
Pascoli V, Turiault M, Luscher C (2011) Reversal of cocaine-evoked synaptic potentiation resets drug-induced adaptive behaviour. Nature 481:71-75.

Pedrazzoli M, Mazzotti DR, Ribeiro AO, Mendes JV, Bittencourt LR, Tufik S (2020) A single nucleotide polymorphism in the HOMER1 gene is associated with sleep latency and theta power in sleep electroencephalogram. PLoS One 15:e223632.

Perroy J, Richard S, Nargeot J, Bockaert J, Fagni L (2002) Permissive effect of voltage on mGlu 7 receptor subtype signaling in neurons. J Biol Chem 277:1223-1228

Perroy J, Raynaud F, Homburger V, Rousset MC, Telley L, Bockaert J, Fagni L (2008) Direct interaction enables cross-talk between ionotropic and group I metabotropic glutamate receptors. J Biol Chem 283:6799-6805.

Petrus E, Rodriguez G, Patterson R, Connor B, Kanold PO, Lee HK (2015) Vision loss shifts the balance of feedforward and intracortical circuits in opposite directions in mouse primary auditory and visual cortices. J Neurosci 35:8790-8801.

Philpot BD, Espinosa JS, Bear MF (2003) Evidence for altered NMDA receptor function as a basis for metaplasticity in visual cortex. J Neurosci 23:5583-5588.

Piard J, Hu JH, Campeau PM, Rzonca S, Van Esch H, Vincent E, Han M, Rossignol E, Castaneda J, Chelly J, Skinner C, Kalscheuer VM, Wang R, Lemyre E, Kosinska J, Stawinski P, Bal J, Hoffman DA, Schwartz CE, Van Maldergem L, et al. (2018) FRMPD4 mutations cause X-linked intellectual disability and disrupt dendritic spine morphogenesis. Hum Mol Genet 27:589-600.

Piton A, Redin C, Mandel JL (2013) XLID-causing mutations and associated genes challenged in light of data from large-scale human exome sequencing. Am J Hum Genet 93:368-383.

Pujol CN, Dupuy V, Seveno M, Runtz L, Bockaert J, Marin P, ChaumontDubel S (2020) Dynamic interactions of the 5-HT6 receptor with protein partners control dendritic tree morphogenesis. Sci Signal 13:eaax9520.

Rakic P (1976) Prenatal genesis of connections subserving ocular dominance in the rhesus monkey. Nature 261:467-471.

Roche KW, Tu JC, Petralia RS, Xiao B, Wenthold RJ, Worley PF (1999) Homer $1 \mathrm{~b}$ regulates the trafficking of group I metabotropic glutamate receptors. J Biol Chem 274:25953-25957.

Rozov A, Zivkovic AR, Schwarz MK (2012) Homer1 gene products orchestrate $\mathrm{Ca}(2+)$-permeable AMPA receptor distribution and LTP expression. Front Synaptic Neurosci 4:4

Sakagami Y, Yamamoto K, Sugiura S, Inokuchi K, Hayashi T, Kato N (2005) Essential roles of Homer-1a in homeostatic regulation of pyramidal cell excitability: a possible link to clinical benefits of electroconvulsive shock. Eur J Neurosci 21:3229-3239.

Sala C, Futai K, Yamamoto K, Worley PF, Hayashi Y, Sheng M (2003) Inhibition of dendritic spine morphogenesis and synaptic transmission by activity-inducible protein Homer1a. J Neurosci 23:6327-6337.

Scheer A, Fanelli F, Costa T, De Benedetti PG, Cotecchia S (1996) Constitutively active mutants of the alpha $1 \mathrm{~B}$-adrenergic receptor: role of highly conserved polar amino acids in receptor activation. EMBO J 15:3566-3578.

Schmitt K, Holsboer-Trachsler E, Eckert A (2016) BDNF in sleep, insomnia, and sleep deprivation. Ann Med 48:42-51.

Serchov T, Clement HW, Schwarz MK, Iasevoli F, Tosh DK, Idzko M, Jacobson KA, de Bartolomeis A, Normann C, Biber K, van Calker D (2015) Increased signaling via adenosine A1 receptors, sleep deprivation, imipramine, and ketamine inhibit depressive-like behavior via induction of Homerla. Neuron 87:549-562.

Shigemoto R, Nomura S, Ohishi H, Sugihara H, Nakanishi S, Mizuno N (1993) Immunohistochemical localization of a metabotropic glutamate receptor, mGluR5, in the rat brain. Neurosci Lett 163:53-57.

Shiraishi-Yamaguchi Y, Furuichi T (2007) The Homer family proteins. Genome Biol 8:206.

Sun P, Zhang Q, Zhang Y, Wang F, Chen R, Yamamoto R, Kato N (2015) Homerla-dependent recovery from depression-like behavior by photic stimulation in mice. Physiol Behav 147:334-341.

Swanson CJ, Baker DA, Carson D, Worley PF, Kalivas PW (2001) Repeated cocaine administration attenuates group I metabotropic glutamate receptor-mediated glutamate release and behavioral activation: a potential role for Homer. J Neurosci 21:9043-9052.

Szumlinski KK, Kalivas PW, Worley PF (2006) Homer proteins: implications for neuropsychiatric disorders. Curr Opin Neurobiol 16:251-257. 
Szumlinski KK, Ary AW, Lominac KD (2008) Homers regulate drug-induced neuroplasticity: implications for addiction. Biochem Pharmacol 75:112133.

Tappe A, Klugmann M, Luo C, Hirlinger D, Agarwal N, Benrath J, Ehrengruber MU, During MJ, Kuner R (2006) Synaptic scaffolding protein Homerla protects against chronic inflammatory pain. Nat Med 12:677-681.

Tononi G, Cirelli C (2014) Sleep and the price of plasticity: from synaptic and cellular homeostasis to memory consolidation and integration. Neuron 81:12-34.

Tronson NC, Guzman YF, Guedea AL, Huh KH, Gao C, Schwarz MK, Radulovic J (2010) Metabotropic glutamate receptor 5/Homer interactions underlie stress effects on fear. Biol Psychiatry 68:1007-1015.

Tu JC, Xiao B, Yuan JP, Lanahan AA, Leoffert K, Li M, Linden DJ, Worley PF (1998) Homer binds a novel proline-rich motif and links group 1 metabotropic glutamate receptors with IP3 receptors. Neuron 21:717726.

van Calker D, Serchov T, Normann C, Biber K (2018) Recent insights into antidepressant therapy: distinct pathways and potential common mechanisms in the treatment of depressive syndromes. Neurosci Biobehav Rev 88:63-72.

Vassart G, Costagliola S (2011) G protein-coupled receptors: mutations and endocrine diseases. Nat Rev Endocrinol 7:362-372.

Vickery ON, Machtens JP, Tamburrino G, Seeliger D, Zachariae U (2016) Structural mechanisms of voltage sensing in $\mathrm{G}$ protein-coupled receptors. Structure 24:997-1007.

Wang M, Lin L, Shi Y, He L, Wang C, Zhu J (2020) Structure of the FERM domain of a neural scaffold protein FRMPD4 implicated in X-linked intellectual disability. Biochem J 477:4623-4634.

Whitt JL, Petrus E, Lee HK (2014) Experience-dependent homeostatic synaptic plasticity in neocortex. Neuropharmacology 78:45-54.

Wigren HK, Schepens M, Matto V, Stenberg D, Porkka-Heiskanen T (2007) Glutamatergic stimulation of the basal forebrain elevates extracellular adenosine and increases the subsequent sleep. Neuroscience 147:811823.

Worley PF, Zeng W, Huang G, Kim JY, Shin DM, Kim MS, Yuan JP, Kiselyov K, Muallem S (2007) Homer proteins in $\mathrm{Ca}^{2+}$ signaling by excitable and non-excitable cells. Cell Calcium 42:363-371.

Xiao B, Tu JC, Petralia RS, Yuan JP, Doan A, Breder CD, Ruggiero A, Lanahan AA, Wenthold RJ, Worley PF (1998) Homer regulates the association of group 1 metabotropic glutamate receptors with multivalent complexes of homer-related, synaptic proteins. Neuron 21:707-716.

Xiao B, Tu JC, Worley PF (2000) Homer: a link between neural activity and glutamate receptor function. Curr Opin Neurobiol 10:370-374

Yamamoto K, Ueta Y, Wang L, Yamamoto R, Inoue N, Inokuchi K, Aiba A, Yonekura H, Kato N (2011) Suppression of a neocortical potassium channel activity by intracellular amyloid-beta and its rescue with Homerla. J Neurosci 31:11100-11109.

Yu SP, Sensi SL, Canzoniero LM, Buisson A, Choi DW (1997) Membranedelimited modulation of NMDA currents by metabotropic glutamate receptor subtypes $1 / 5$ in cultured mouse cortical neurons. J Physiol 499:721-732.

Yuan JP, Kiselyov K, Shin DM, Chen J, Shcheynikov N, Kang SH, Dehoff MH, Schwarz MK, Seeburg PH, Muallem S, Worley PF (2003) Homer binds TRPC family channels and is required for gating of TRPC1 by IP3 receptors. Cell 114:777-789.

Zhang GC, Mao LM, Liu XY, Parelkar NK, Arora A, Yang L, Hains M, Fibuch EE, Wang JQ (2007) In vivo regulation of Homerla expression in the striatum by cocaine. Mol Pharmacol 71:1148-1158.

Zheng Y, Qin L, Zacarías NV, de Vries H, Han GW, Gustavsson M, Dabros M, Zhao C, Cherney RJ, Carter P, Stamos D, Abagyan R, Cherezov V, Stevens RC, IJzerman AP, Heitman LH, Tebben A, Kufareva I, Handel TM (2016) Structure of CC chemokine receptor 2 with orthosteric and allosteric antagonists. Nature 540:458-461. 